\title{
The Influence of Respondent Characteristics and Different Areas on Small-Scale Fisherman Household Income of Urban Coastal Areas in Pare-Pare City, South Sulawesi
}

\author{
Abd. Rahim ${ }^{1 *}$, Diah Retno Dwi Hastuti ${ }^{1}$, Dita Pradipta ${ }^{1}$, \\ Nurbaya Bustanul' ${ }^{2}$, and Nur Azizah ${ }^{3}$ \\ ${ }^{1}$ Study program of Development Economics, Faculty of Economics, State University of Makassar \\ ${ }^{2}$ Departement of Socioeconomic, Faculty of Agriculture, Universitas Hasanuddin, Makassar \\ ${ }^{3}$ Study Program of Agribussines, Faculty of Agriculture and Forestry, Universitas Nuku, North Maluku
}

(Received October 04, 2018; accepted October 15, 2018; published November 8, 2018)

\begin{abstract}
Traditional fishermen are small-scale fisheries with small-scale catches. They are commonly found in coastal areas and become one of the main income source of coastal communities in developing countries. They use simple fishing gear and small boats in fishing, such as outboard motor and nonpowered motor. The changing of seasons (arrest and famine) in Makassar Strait Waters Bordered which is directly to the West coastal area of Pare-Pare City of South Sulawesi Province Indonesia result in the change of the catch and income production of the catching business. That affects the change of household income, especially the small-scale fishermen outboard motor. The multiple regression econometrics analysis method with independent variable estimation model qualitative was applied. The census technique was used in this study with the total of 42 respondents. The findings indicate that the age as the characteristics of the fisherman respondents and the difference of residence areas have an effect on the change of household income of small-scale fisherman. Meanwhile the education, family dependent, and the experience of going to sea do not affect the household income. The productive fishermen has a better physical ability to make an optimal capture for the welfare of their family in meeting the needs in their household.
\end{abstract}

Keywords: household income, fisherman, and small-scale

JEL Classification: D19, Q18, Q22

\section{INTRODUCTION}

The existence of seasonal changes (arrest and famine) in Indonesian waters particulary in the Makassar Strait Bordering on the western coastal areas of Pare-Pare City result changes in the production of catch, productivity, fluctuations in catch fish prices (Rahim et al., 2018) and its capture income (Rahim \& Hastuti, 2016). That affects the economic changes of households as well (Jeyarajah \& Santhirasegaram, 2015; Rahim, 2018), especially of small-scale fisherman coastal.

\footnotetext{
* Corresponding author email: abd.rahim@unm.ac.id, ORCID ID https://orcid.org/0000-0002-1720-7150 ISSN 2615-6075 online; ISSN 2615-6946 print @UWG Press, 2018

OJS http://publishing-widyagama.ac.id/ejournalv2/index.php/jsed/
}

Traditional fishermen are small-scale fisheries (Pomeroy \& Andrew, 2011; Gebremedhin, Budusa, Mingist, \& Vijverberg, 2013) with small-scale catches (Lopes \& Begossi, 2011; Rabearisoa \& Zorzi, 2013 ; Panagopoulou, Meletis, Margaritoulis, \& Spotila, 2017). They are commonly found in coastal areas and become one of the main income source of coastal communities in developing countries (Pomeroy \& Andrew, 2011; BarnesMauthe, Oleson, \& Zafindrasilivonona, 2013). They use simple fishing gear in fishing and boats in sizes not exceeding 5 GT (gross tonnage), including outboard motors and boats without motors (Gebremedhin et al., 2013). Whereas, according to Law No. 45 of 2009 on fisheries in Indonesia that small-scale fishermen are small fishermen with the size of fishing vessels owned by the largest 5 GT. In Indonesia, the fishing population is dominated by small-scale fishermen, in which $95 \%$ of them is 
traditional fishermen (Sudarmo, Baskoro, Wiryawan, Wiyono, \& Monintja, 2015)

Although traditional fishing contributions are often lack in quantification (Barnes-Mauthe et al., 2013), they have contributed significantly to the coastal economic development. In addition, they contribute to sustainable livelihoods (Evans \& Andrew, 2011), support livelihoods and welfare for more than $\mathbf{5 0 0}$ million coastal activists in Indonesia and other developing countries (Pomeroy \& Andrew, 2011; Barnes-Mauthe et al., 2013) in poverty alleviation and food security.

The majority of traditional fishermen have characteristics as poor (Asiedu, Nunoo, OforiDanson, Sarpong, \& Sumaila, 2013; Etuk, Angba, \& Angba, 2015), and is largest in coastal strata in many developing countries (Zamroni \& Yamao, 2011). Most of them have low income in fishing (Barnes-Mauthe et al., 2013) with limited resources and frequent conflicts with large-scale fisheries and facing uncertain climatic conditions (Gamito, Teixeira, Costa, \& Cabral, 2015a; Mohammed et al., 2017) due to changes in fishing season (Adili \& Antonia, 2017; Brillo, Elazegui, Cervantes, \& Rola, 2018). This has an impact on household income (Long \& Yabe, 2011; Dachin \& Mosora, 2012; Rahim et al., 2018) and consumption expenditures (Oladimeji, Abdulsalam, Damisa, \& Omokore, 2015).

Factors influencing Fisherman household income has been studied in many countries such as in Sri Lanka (Jeyarajah \& Santhirasegaram, 2015), and Tanzania (Adili \& Antonia, 2017), as well as in Indonesia itself (Primyastanto, 2015). However, the study has not discussed specifically on the influence of respondent characteristics and regional differences on changes in household income of motor boat fishermen in coastal urban areas.

The objectives of the International Fisheries Policy through the Fisheries Committee (COFI) and the Subcommittee are to support sustainable development and small fisheries protection, since small-scale fisheries generate two-thirds of all catches targeted for direct human consumption and provide $90 \%$ of employment in this sector (Food and Agriculture Organization (FAO), 2015). Meanwhile, the objectives of fisheries development in Indonesia are improving the welfare of fishermen, fish farmers and other coastal communities (Keputusan Menteri Kelautan dan Perikanan No.18/Men/2002) through the development of economic activities, quality improvement and quantity of resources (Keputusan Menteri Kelautan dan Perikanan No.18/Men/2004), sustainability, sovereignty and welfare (Peraturan Menteri Kelautan dan Perikanan No. 45/ PermenKP/ 2015).

In short, the purpose of this paper is to estimate the influence of respondent characteristics and regional differences on the change in household income of outboard motor traditional fishermen in urban coastal area by using econometric estimation model approach of qualitative independent variables (Gujarati \& Porter, 2009) in coastal area of West Coast of ParePare City, South Sulawesi Province, Indonesia as a case study.

\section{RESEARCH METHOD}

The study was conducted in the Coastal Areas of Pare-Pare City. It used explanatory methods for estimating household income of small-scale fishermen coastal and Cross-section data from household fisherman survey. Questionnaires were given to 42 respondents by implementing census techniques. The analytical method used was multiple regression with the exponential function model (Gujarati \& Porter, 2009). It was to analyze the income estimation of small-scale fisherman.

$\pi S S F H=\beta_{0} A g F^{\beta 1} F E d^{\beta 2} Q F C^{\beta 3} \operatorname{ExpS}^{\beta 4} \delta R D^{\mu}$

To facilitate the mathematical calculation of equation (1), it is used the double log or natural logarithm (Ln) of Gujarati and Porter (2009) as follows:

$$
\begin{aligned}
\pi S S F H= & \operatorname{Ln} \beta_{0}+\beta_{1} \operatorname{LnAgF}+\beta_{2} \operatorname{LnFEd}+ \\
& \beta_{3} \operatorname{LnQFC}+\beta_{4} \operatorname{LnExpS}+\delta R D+\mu
\end{aligned}
$$

Where $\pi S S F H$ : household income of outboard motor fishermen (IDR), $\beta_{0}$ : intercept, $\beta_{1}, \ldots, \beta_{5}$ : regression coefficient, $A g F$ : the age of household head (year), FEd: formal education (year), QFC: quantity of family counts (People), ExpS : experience to go to sea (year), Dummy regional 
differences, $\delta R D: 1$, Village of Sumpang Minangae; 0 , Other, and $\mu$ : Error term

The appropriateness of the measurement or suitability of the model (goodness of fit) was calculated by adjusted $\mathrm{R}^{2}$. According to (Gujarati \& Porter, 2009), it is formulated as follows:

Adjusted $R^{2}=1-\left(1-R^{2}\right) \frac{(n-1)}{(k-1)}$

Where Adjusted $\mathrm{R}^{2}$ : the coefficient of determination adjusted; $\mathrm{k}$ : the number of variables not included intercept; $n$ : the number of samples.

The hypothesis testing of regression coefficients used the F-test with a certain level of confidence (Gujarati \& Porter, 2009), it is formulated as follows:

$$
\begin{aligned}
& F \text { test }=\frac{E S S /(k-1)}{R S S /(n-k)} \\
& F \text { table }[(k-1):(n-k) ; \alpha]
\end{aligned}
$$

where $\alpha$ level of significance or specification error. The testing of individual regression coefficients (partial) used t-test with a certain level of confidence. The formula is (Gujarati \& Porter, 2009):

$$
\begin{aligned}
& \text { t test }=\frac{\beta i}{s \beta i} \\
& \text { t table }[(n-) ; \alpha /]
\end{aligned}
$$

where $\beta$ : regression coefficient of $i, S \beta_{i}$ : error standard of regression coefficients to-i

Furthermore, multi-collinearity test used the Variance Inflation Factor (VIF) method: (Gujarati \& Porter, 2009)

$$
V I F=\frac{1}{1-R_{j}^{2}}
$$

$\mathrm{R}^{2}{ }_{j}$ was received from Auxiliary Regression between the independent variables and dependent variables, where if VIF $<10$, it means that there is not multi-collinearity (Gujarati \& Porter, 2009). Meanwhile, the heteroscedasticity test was conducted in disturbance variable form once unknown variance of disturbance variable $\left(\sigma_{i}^{2}\right)$.
Thus, the residual $\left(\hat{\mathrm{e}}_{i}^{2}\right)$ of regression results as proxy of residual $\hat{e}_{i}^{2}$ : (Gujarati \& Porter, 2009)

$$
\operatorname{Ln} \hat{\mathrm{e}}_{i}^{2}=\operatorname{Ln} \sigma^{2}+\beta \operatorname{Ln} X_{i}+v_{i}
$$

If the coefficient of $\beta$ is not significant through t-test, therefore, it can be concluded that there is no heteroscedasticity. Instead, if $\beta$ is significant, hence the model contains heteroscedasticity.

\section{RESULT AND DISCUSSION}

Pare-pare City is one of the areas in South Sulawesi that has a strategic position because it is located in the path of land transportation and sea transportation, both North - South and East - West direction, with an area of $99.33 \mathrm{~km}^{2}$ geographically located between $3^{\circ} 57$ '39 "- $4^{\circ} 04$ '49 "South Latitude and $119^{\circ} 36^{\prime} 24^{\prime \prime}$ - 119043 '40 "East Longitude. It consists of 4 sub-districts, Bacukiki, Ujung, Soreang, and Bacukiki Barat, and 22 (4kban villages, which are administratively bordered by District of Pinrang in the North, District of Sidenreng Rappang in the east, District of Barru, and to the west by the Makassar Strait (Figure 1).

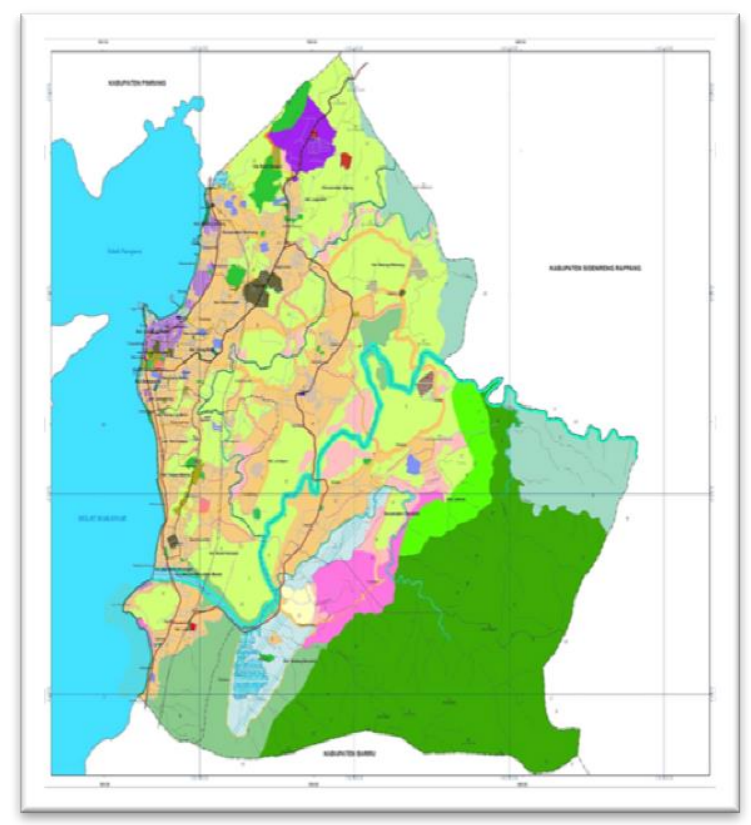

Figure 1. Map of Pare-pare, South Sulawesi

The area of Pare-pare City when viewed from the topography aspect consists of flat to wavy areas, with a classification of approximately $80 \%$ of the area is a hilly area and the rest flat area with a 
height of 25 - 500 meters above sea level, wavy and hilly terrain $(88.96 \%)$ with dominant functions for plantation land $(18.56 \%)$, forestry $(43.04 \%)$, settlement areas $(1.57 \%)$, and small areas are flat to sloping lowlands $(11.04 \%)$ with settlement function $(2.80 \%)$, agriculture $(9.40 \%)$ and fisheries $(0.24 \%)$.

The most territory of Pare-pare City is located in the height or hills, especially in the Sub-District of Bacukiki with an altitude $>500$ meters above the sea level. Meanwhile, Ujung Sub-district and Soreang Sub-district are located at the altitude of 0-500 meters above the sea level. This condition shows that the morphology of Pare-pare City is divided into low and high (hills/mountains).

The analysis of the influence of fisherman respondents' characteristic (age, last education, number of family dependent, experience) and the difference of fisherman's residence area to household income of traditional coastal fisherman in Pare-Pare City used multiple regression analysis model and classical assumption test of multicollinearity and heteroscedasticity.

The results of multi-collinearity testing with variance inflection factor (VIF) (Gujarati \& Porter, 2009) method do not show or indicate multicollinearity or double collinearity since VIF values $A=\pi r^{2}$ are less than 10 (Table 1). Furthermore, the heteroscedasticity testing by using park test (Gujarati \& Porter, 2009), the error variables as dependent variable regression with each independent variable and the coefficient value $(\beta)$ is not significant. Then it is concluded that there is no heteroscedasticity (Table 1).

Table 1. The Results of Validity Testing

\begin{tabular}{lll}
\hline Independent Variable & VIF & Park Test \\
\hline & 1.445 & $1.429^{\text {ns }}$ \\
FEd & 1.473 & $0.105^{\text {ns }}$ \\
QFC & 2.930 & $0.204^{\text {ns }}$ \\
& 1.600 & $0.257^{\text {ns }}$ \\
& 1.169 & $0.153^{\text {ns }}$ \\
\hline
\end{tabular}

If the VIF value is less than 10 , it means that there is no multicollinearity. Otherwise, If VIF value is greater than 10 , it means that multi-collinearity occurs, ns $=>$ not significant; if $\beta$ value is not significant, there is no availability of heteroscedasticity. Otherwise, if the value of $\beta$ is significant, there is heteroscedasticity.

The measurement of the accuracy model of adjusted $R^{2}$ showed that the independent variables in the seaweed production function model presented can explain each percentage of contribution of independent variables (age, formal education, quantity of family dependents, experience, and difference of fisherman's residence) for $62.4 \%$ of the variation (ups and downs) of non-free variables (household income). Meanwhile, the others of $37.6 \%$ were contributions from other factors that are not included in the model (Table 2).

The results of the F-test showed that seaweed production function significantly affects the error rate of 1 percent (Table 2). It can be interpreted that all independent variables simultaneously have a significant effect on small-scale fisherman household income. Furthermore, the individual influence (partial) from each independent variable to small-scale fisherman household income used ttest and regression coefficient value in the discussion.

Table 2. Estimate of Variables Influencing Household Income

\begin{tabular}{lllr}
\hline $\begin{array}{c}\text { Independent } \\
\text { Variable }\end{array}$ & E.S & $\beta$ & t-test \\
\hline$A g F$ & + & $1.091^{* *}$ & 6.381 \\
$F E d$ & + & 0.061 & 0.423 \\
$Q F C$ & + & 0.177 & 1.329 \\
$E x p S$ & + & 0.036 & 0.440 \\
$\delta R D$ & + & $0.253 * * *$ & 3.338 \\
\hline Intercept & & & 10.436 \\
F-test & & & 12.364 \\
Adjusted $R^{2}$ & & & 0.624 \\
$\mathrm{n}$ & & 42 \\
\hline$* * *$ S Significant error rate of $1 \%(0.01)$, or $99 \%$ confidence \\
level. ** = Significant error rate of 5\% $(0.05)$, or $95 \%$ confidence \\
level. ns = not significant. E.S is an expectation sign.
\end{tabular}

The variable of fisherman age as respondent characteristic has positive effect to household income of fisherman catch in Pare-Pare City. This finding is in line with (Jeyarajah \& Santhirasegaram, 2015), which was conducted in Sri Lanka. However, it is in contrast to the research in the West Coast Coastal Area of Barru District Indonesia that the age negatively affects the income of traditional catch fishermen in Barru District South Sulawesi Province (Rahim \& Hastuti, 2016), and thus affects the household economy (Oladimeji et al., 2015), (Rahim \& Hastuti, 2018)). It means that the increasing age of fishermen will 
indirectly decrease their income due to decreased productivity of the sea.

Empirically, there is a difference on the average age of traditional fisherman in Bacukiki Barat District. There are 8 people (29.62\%) in the age of 25-30 years old in Sumpang Minangae Sub-District and 4 people $(26.66 \%)$ in Lumpue Village. These fishermen are still in a productive age in working although they are 51-55 years old who belong to non-productive age. These results are in line with the findings of Tzanatos et al. (2006a) in which there are significant differences among groups in the age of fishermen to increase the annual income of fishing activities in Greece.

According to Pakpahan, Lumintang, \& Susanto (2006) the fishermen age who are young around 30 s are in the productive age. It is because they have good physical ability so that they can perform activities optimally and able to develop themselves by giving priority to the success of their family welfare especially to meet the children needs. Furthermore, according to the International Labor Organization Convention (ILO) No. 199 of 2007 concerning to fishing jobs, the age of 16 to 18 years old who is prior to arrest should be given a training in the form of apprentices for work safety in not more than eight hours per day and 40 hours per week. They should not also work overtime except when it cannot be avoided for safety reasons.

Furthermore, the variable characteristic of respondents in the form of formal education does not have an effect on the household income of the fisherman catch in Pare-Pare City. This finding is inconsistent with the prior research (Adili \& Antonia, 2017) in Tanzania in the Indian Ocean that education affects household incomes of the fishermen.

The formal education of the fishermen in Parepare City has no significant effect because their society generally gets knowledge to go to sea only from the hereditary of their parents who work as fishermen as well. This is proved empirically from the largest number of fishermen respondents who only graduated from primary school (elementary) and junior high (SMP), 31 fishermen from 42 fishermen respondents. According to Riptanti (2005), although formal education can be used as one indicator to measure productivity, the higher the level of education it has, the higher the productivity and the ability to manage the business catch and dare to take risks in the business. Moreover, education status may reduce the chances of becoming poor (Etuk et al., 2015).

The low level of fishermen education in their families is because of family's economic limitations and the inability of parents to send their children to school, so they need to quit school and spend more time at home or helping their parents (Hutapea et al., 2012; Rahim \& Hastuti, 2018).

Furthermore, the quantity variable of family dependents has no effect on household income of the fishermen. These results are not in line with Jeyarajah \& Santhirasegaram (2015) who find that family size negatively affects the income of fisherman households in Sri Lanka, while Parvin \& Akteruzzaman (2012) finds positive effect on household income from agriculture and non Agriculture in Bangladesh.

Empirically, the average number of fishermen dependents in Pare-pare City are 2-3 family members. The large number of family members who will use a small amount of income will result in low levels of consumption because the number of family dependents will encourage fishermen to work harder to meet the needs of their family members (Rahim \& Hastuti, 2016).

Further experience of fishing also has no effect on household income of the fishermen in Pare-Pare City. This result is not in line with the findings of Primyastanto (2015) that the experience of going to sea affects the change in household income of Pandega fishermen in the Madura Strait. The average experience of fishing at Pare-Pare City was 31-35 years with the total number of fishermen is 3 (17.3\%) and the lowest is 5-10 years for 11 fishermen (52.58\%). The benefits of education are investment (Rahim \& Hastuti, 2018) for increasing the income, consumption and their welfare (Agarwal, Rahman, \& Errington, 2009; Rabearisoa \& Zorzi, 2013) because the higher the level of education, the more rational the decision will be. Thus, it leads to improve welfare economy of their family.

The differences in the production of traditional fisherman catches in each water directly adjacent 
to the sub-districts / villages in the western coastal areas of Pare-pare as their dummy variables certainly affect household economics, especially household income. According to Fahrunnisa, Azhar, Muswar, Miharja, \& Fahmi (2015), coastal fishing communities are groups of people living in coastal areas with distinctive cultures associated with their dependence on the utilization of coastal resources in economic activity and have the right to have collective resources that provide the benefits and efficiency of the existing resources sustainability.

Dummy difference of fisherman residence area has a significant positive effect to household income of traditional fisherman in Pare-Pare City. This result has been proven that the income of fisherman households out of Sumpang Minangae is 1.954 million rupiahs higher than Lumpue Village i.e. 868 thousand rupiahs. It means that there is a significant difference between the traditional fishermen's residence in the area from the fishing activities. That is in accordance with the finding of (Rahim \& Hastuti, 2016) that in Barru District the income is smaller i.e. the average per trip is 468 thousand rupiahs for boat fisherman and boats without motorcycles of 191 thousand rupiahs. Meanwhile, (Adili \& Antonia, 2017) finds that in Tanzania, the averaged per day of 24.41 USD (51250 TZS) as a household economic enhancer, as well as in Sri Lanka the average monthly household income amounted to 18.284 thousand rupees (Jeyarajah \& Santhirasegaram, 2015).

The efforts to increase fishermen household income can be done by on-fishing and off-fishing. On-fishing can be carried out by the head of the household itself, namely the fisherman through fishing efforts (Zhao, Tyzack, Anderson, \& Onoakpovike, 2013) with the support of a 10-20 power knot (PK) outboard motor to reach fishing ground as a fishing area in the Exclusive Economic Zone (EEZ), 6 to 12 miles equipped with modern fishing gear in the form of fishing rods and nets (Rahim \& Hastuti, 2016).

Furthermore, off-fishing is done by utilizing free time outside fishing (Nazmar, 2014) by household members, for example the wife of a fisherman who is not only a housewife, but also as the head of the family when fishermen go to the sea (Marini \& Ningsih, 2015). Off-fishing activities include postharvest handling, handling, processing (Azizi,
Hikmah, \& Pranowo, 2012) and marketing of marine products (Biswas \& Rao, 2014), so that they have profound implications for management, rural poverty alleviation policies (Khodijah, 2014), and economic development of fisheries throughout the world (Harper, Zeller, Hauzer, Pauly, \& Sumaila, 2013).

\section{CONCLUSION AND SUGGESTION}

The characteristics of respondents in the form of age and the difference of residence give an influence to the change of income of traditional fisherman households. Meanwhile, the education, family dependent, and experience of going to sea have no effect to household income. The age of productive fishermen of course have a better physical ability to make an optimal capture for the welfare of their family in meeting the needs in their households.

Increased fisherman household income can be done by on-fishing and off-fishing. On-fishing is carried out by the fishermen themselves as the head of the household through fishing efforts with the support of an outboard motor with power knots (PK) equipped with modern fishing gear to reach fishing ground as a fishing area in the Exclusive Economic Zone (EEZ). Whereas, off-fishing is done by utilizing free time outside fishing of the fisherman wives themselves in the form of postharvest handling, handling, processing and marketing of marine products as a way of implicating rural poverty alleviation policies and fisheries economic development.

\section{ACKNOWLEDGMENT}

We would like to thank to the Study Program of Development Economic, Faculty of Economics and Research Institute of Universitas Negeri Makassar (UNM) and the Government of South Sulawesi to enable this research. Besides that, we would also like to thank to the Department of Maritime Affairs and Fisheries and the Pare-Pare City Bureau of Statistics and all respondents for supporting in collecting the data.

\section{REFERENCES}

Adili, Z., \& Antonia, M. (2017). Determinants Influencing Fishing Income to the Coastal Households of Indian Ocean. Oceanogr Fish Open Access J, 4(3), 1-7. 
https://doi.org/10.19080/OFOAJ.2017.04.55564 $\underline{0}$

Agarwal, S., Rahman, S., \& Errington, A. (2009). Measuring the determinants of relative economic performance of rural areas. Journal of Rural Studies, 25(3), 309-321. https://doi.org/10.1016/i.jrurstud.2009.02.003

Asiedu, B., Nunoo, F. K. E., Ofori-Danson, P. K., Sarpong, D. B., \& Sumaila, U. R. (2013). Poverty Measurements in Small-scale Fisheries of Ghana: A Step towards Poverty Eradication. Current Research Journal of Social Sciences, 5(3), 75-90. Retrieved from https://dlc.dlib.indiana.edu/dlc/bitstream/handle 110535/9030/v5-7590.pdf?sequence $=1$ \&isAllowed $=y$

Azizi, A., Hikmah, \& Pranowo, S.A. (2012) Peran Gender Dalam Pengambilan Keputusan Rumah Tangga Nelayan di Kota Semarang Utara Provinsi Jawa Tengah, Jurnal Sosial Ekonomi Kelautan dan Perikanan, 7, 113-125. Retrieved from http://ejournalbalitbang.kkp.go.id/index.php/sosek/article/view $\lcm{5740}$

Barnes-Mauthe, M., Oleson, K. L. L., \& Zafindrasilivonona, B. (2013). The total economic value of small-scale fisheries with a characterization of post-landing trends: An application in Madagascar with global relevance. Fisheries Research, (147), 175-185. https://doi.org/10.1016/j.fishres.2013.05.011

Biswas, M., \& Rao, M. (2014). Fisherwomen of the East Coastal India: A Study. International Journal of Gender and Women's Studies, 2(2), 297-308. Retrieved from https://pdfs.semanticscholar.org/b50d/772d363 1b665e35775714c1eddcbaeecc743.pdf

Brillo, B. B. C., Elazegui, D. D., Cervantes, C. P., \& Rola, A. C. (2018). Impact of the closed fishing season policy for sardines in Zamboanga Peninsula, Philippines. Marine Policy., (87), 4050.

https://doi.org/10.1016/j.marpol.2017.09.029

Dachin, A., \& Mosora, L.-C. (2012). Influence Factors Of Regional Household Income Disparities In Romania. Journal of Social and Economic Statistic, 1(1), 78-93. Retrieved from http://ises.ase.ro/downloads/current issue/5.D achin final.pdf

Etuk, E., Angba, C., \& Angba, A. (2015). Determinants of Poverty Status of Fish Vendor Households in Lower Cross River Basin, Nigeria. Journal of Economics and Sustainable
Development Www.Iiste.Org ISSN, 6(14), 50$55 . \quad$ Retrieved from https://iiste.org/Journals/index.php/JEDS/article /view/24423/24999

Evans, L., \& Andrew, N. (2011). Diagnosis and the management constituency of small-scale fisheries (Working Paper, The World Fish Center No. 1941). Penang, Malaysia. Retrieved from http://aquaticcommons.org/2575/1/WF 2416.p df

Fahrunnisa, Azhar, H., Muswar, H. S., Miharja, H. A., \& Fahmi, A. (2015). DILEMA AGRARIA PESISIR (Studi Kasus Masyarakat Pesisir Dusun Ujung Genteng Kabupaten Sukabumi). Sodality: Jurnal Sosiologi Pedesaan, 3(3), 107-113. https://doi.org/10.22500/sodality.v3i3.10641

Food and Agriculture Organization (FAO). (2015). Voluntary Guidelines for Securing Sustainable Small-Scale Fisheries in the Context of Food Security and Poverty Eradication. Rome: FAOUN. Retrieved from http://www.fao.org/3/ai4356en.pdf

Gamito, R., Teixeira, C. M., Costa, M. J., \& Cabral, H. N. (2015). Are regional fisheries' catches changing with climate? Fisheries Research, (161), 207-216. https://doi.org/10.1016/j.fishres.2014.07.014

Gebremedhin, S., Budusa, M., Mingist, M., \& Vijverberg. (2013). Determining Factors For Fishers' Income: The Case Of Lake Tana, Ethiopia. International Journal of Current Research, 5(5), 1182-1186. Retrieved from https://pure.knaw.nl/portal/files/477986/Gebre medhin et al. (2013).pdf

Gujarati, D. N., \& Porter, D. . (2009). Basic Econometrics. (5th ed.). New York: McGraw-Hill Irwin. Retrieved from https://books.google.co.id/books/about/Basic E conometrics.html?id=611CPgAACAAJ\&redir esc $\equiv y$

Harper, S., Zeller, D., Hauzer, M., Pauly, D., \& Sumaila, U. R. (2013). Women and fisheries: Contribution to food security and local economies. Marine Policy, 9(1), 56-63. https://doi.org/10.1016/j.marpol.2012.10.018

Hutapea, R. Y. F., Kohar, A., Rosyid A. (2012). Peranan Wanita Nelayan (Istri Nelayan) Jaring Insang dalam Meningkatkan Pendapatan Keluarga di Desa Bejalen, Perairan Rawa Pening, Kecamatan Ambarawa, Kabupaten Semarang. Journal of Fisheries Resources Utilization Management and Technology, 1(1), 
1-10. Retrieved from http://www.ejournals1.undip.ac.id/index.php/ifrumt1

Jeyarajah, S., \& Santhirasegaram, S. (2015). Socio Economic Factors Influencing Marine Small Scale Fishers' Income in the Batticaloa District of Sri Lanka. The International Journal of Humanities \& Social Studies, 3(1), 75-79. Retrieved from http://theijhss.com/force download.php?file pa th=wp-content/uploads/2015/03/12.-HS1501027.pdf\&id $=514$

Khodijah. (2014). Sustainable livelihoods of fishermen households headed by women (case study in Riau Islands Province of Indonesia). Asian Social Science, 10(9), 187-196. https://doi.org/10.5539/ass.v10n9p187

Long, H. Van, \& Yabe, M. (2011). Factors Affecting to Household Income of The Kinh and The Ethnic Minority in Rural Vietnam: A Case Study in The Buffer Zone of Bach Ma National Park. Asian-African Journal of Economics and Econometrics, 11(1), 135-145. https://doi.org/http://serialsjournals.com/archiv es.php?journals id=10

Lopes, P. F. M., \& Begossi, A. (2011). Decisionmaking processes by small-scale fishermen on the southeast coast of Brazil. Fisheries Management and Ecology, 18(5), 400-410. https://doi.org/10.1111/j.1365$\underline{\text { 2400.2011.00795.x }}$

Marini, I. A. K., \& Ningsih, N. S. K. (2015). Ragam Aktivitas Ekonomi Wanita Nelayan Terhadap Peningkatan Pendapatan Rumah Tangga Nelayan di Kota Mataram. Jurnal Ganeç Swara, 9(1), 53-59. Retrieved from http://unmasmataram.ac.id/wp/wpcontent/uploads/7.Marini.pdf

Mohammed, K. K., Dash, G., Kumari, S., Sreenath, K. R., Makwana, N. P., Sen Dash, S., ... Zacharia, P. U. (2017). Vulnerability of coastal fisher households to climate change: A case study from Gujarat, India. Turkish Journal of Fisheries and Aquatic Sciences, 17(1), 193-203. https://doi.org/10.4194/1303-2712-v17 121

Nazmar, E. (2014). Upaya Peningkatan Ekonomi Rumah Tangga Nelayan Skala Kecil dengan Memanfaatkan Waktu Luang di Luar Penangkapan Ikan (Off-Fishing) di Kota Padang. Apresiasi Ekonomi, 2(1), 15-25. Retrieved from https://media.neliti.com/media/publications/402 28-EN-upaya-peningkatan-ekonomi-rumahtangga-nelayan-skala-kecil-denganmemanfaatkan-w.pdf
Oladimeji, Y., Abdulsalam, Z., Damisa, M., \& Omokore, D. (2015). Analysis of Food Consumption Pattern among Rural Fishery Households: A Panacea to Poverty Alleviation in North Central Nigeria. Asian Journal of Agricultural Extension, Economics \& Sociology, 6(2), 102-110. https://doi.org/10.9734/AJAEES/2015/17388

Pakpahan H.T., Lumintang, R.W.E, \& Susan, D. (2006). Hubungan Motivasi Kerja Dengan Perilaku Nelayan Pada Usaha Perikanan Tangkap. Jurnal Penyuluhan. 2(1), 26-34. https://doi.org/http://dx.doi.org/10.25015/peny uluhan.v2i1.2138

Panagopoulou, A., Meletis, Z. A., Margaritoulis, D., \& Spotila, J. R. (2017). Caught in the Same Net? Small-Scale Fishermen's Perceptions of Fisheries Interactions with Sea Turtles and Other Protected Species. Frontiers in Marine Science, 4, 180. Retrieved from https://www.frontiersin.org/article/10.3389/fma rs.2017.00180

Parvin, M.T., \& Akteruzzaman, M. (2012). Factors Affecting Farm and Non-Farm Income of Haor Inhabitants of Bangladesh. Progression $\begin{array}{llll}\text { Agriculture. } & 23 & \text { (1), 143-150. }\end{array}$ https://doi.org/10.3329/pa.v23i1-2.16578

Pomeroy, R., \& Andrew, N. (2011). Small-scale Fisheries Management Small-scale Fisheries Management Frameworks and Approaches for the Developing World. Malaysia: WorldFish Center. Retrieved from https://www.cabi.org/bookshop/book/97818459 $\underline{36075}$

Primyastanto, M. (2015). Economic Analysis Of Pandega Fishermen Household At Madura Strait To Keep Food Security. International Journal of Oceans and Oceanography, 9(2), 97-104. Retrieved from https://www.ripublication.com/Volume/ijoov9n2 .htm

Rabearisoa, A. L., \& Zorzi, E. (2013). An Economic Return to Education in Small-scale Fisheries in North-East Madagascar. Western Indian Ocean J. Mar. Sci, 12(2), 185-188. Retrieved from https://www.ajol.info/index.php/wiojms/article/ download/77858/100600

Rahim, A. (2018). The Empowerment Strategy of The Traditional Fisherman's Wives in The Coastal Area of Barru Regency, South Sulawesi. Journal of Socioeconomics and Development, 1(1), $1-6$. https://doi.org/10.31328/jsed.v1i1.515 
Rahim, A., \& Hastuti, D. (2016). Determinants of Traditional Fishing Income in West Coast of Barru Regency. Jurnal Sosial Ekonomi Kelautan Dan Perikanan., 11(1), 75-88. Retrieved from http://ejournal-

balitbang.kkp.go.id/index.php/sosek/article/view File/3173/2680

Rahim, A., \& Hastuti, D. (2018). Applied Multiple Regression Method with Exponential Functions: an Estimation of Traditional Catch Fishermen Household Income. IOP Conf. Series: Journal of Physics: Conf. Series, 1028, 12177. https://doi.org/10.1088/17426596/1028/1/012177

Rahim, A., Hastuti, D.R.D., Ningsih, S.R., Mardia, Nuryanti, D.M., Patta, A.A., Yatim, H., \& Hayat, N.Z. (2018). The Influence of Marketing Volume and Marketing Channel on Fresh Tiger Shrimp Marketing Margin. Indonesian Journal of Fundamental Sciences, 4(1),16-23. Retrieved from

http://ojs.unm.ac.id/pinisi/article/view/6011/34 $\underline{27}$

Riptanti, E. W. (2005). Karakteristik dan Persoalan Ekonomi Masyarakat Petani dan Nelayan pada Kawasan Pantai di Torosiaje Kabupaten Pohuwatu. Caraka Tani (Jurnal Ilmu-IImu Pertanian)., 22(2), 55-68. Retrieved from https://jurnal.uns.ac.id/carakatani/article/view/2 $\underline{0492}$
Sudarmo, A.P., Baskoro, M.S., Wiryawan, B., Wiyono, E.S. \& Monintja., D. R. (2015). Social Economics Characteristics of Coastal SmallScale Fisheries In Tegal City, Indonesia. International Journal of Scientific \& Technology Research. 4(1), 85-88. Retrieved from http://www.ijstr.org/final-print/jan2015/SocialEconomics-Characteristics-Of-Coastal-Smallscale-Fisheries-In-Tegal-City-Indonesia.pd

Tzanatos, E., Dimitriou, E., Papaharisis, L., Roussi, A., Somarakis, S., \& Koutsikopoulos, C. (2006). Principal socio-economic characteristics of the Greek small-scale coastal fishermen. Ocean and Coastal Management, 49(7-8), 511-527. https://doi.org/10.1016/j.ocecoaman.2006.04.0 $\underline{02}$

Zamroni, A., \& Yamao, M. (2011). Sustainable Household Economics: A Case of Altering Income of Small-Scale Fishermen in Indonesia. International Conference On Financial Management and Economics, 11, 343-347

Zhao, M., Tyzack, M., Anderson, R., \& Onoakpovike, E. (2013). Women as visible and invisible workers in fisheries: A case study of Northern England. Marine Policy, 37(1), 69-76. https://doi.org/10.1016/j.marpol.2012.04.013 